\title{
Decolonizing Philosophy of Technology: Learning from Bottom-Up and Top-Down Approaches to Decolonial Technical Design
}

\section{Cristiano Codeiro Cruz $^{1}$ (D)}

Received: 15 February 2021 / Accepted: 21 October 2021 / Published online: 10 November 2021

(c) The Author(s) 2021

\begin{abstract}
The decolonial theory understands that Western Modernity keeps imposing itself through a triple mutually reinforcing and shaping imprisonment: coloniality of power, coloniality of knowledge, and coloniality of being. Technical design has an essential role in either maintaining or overcoming coloniality. In this article, two main approaches to decolonizing the technical design are presented. First is Yuk Hui's and Ahmed Ansari's proposals that, revisiting or recovering the different histories and philosophies of technology produced by humankind, intend to decolonize the minds of philosophers and engineers/architects/designers as a pre-condition for such decolonial designs to take place. I call them top-down approaches. Second is some technical design initiatives that, being developed alongside marginalized/subalternate people, intend to co-construct decolonial sociotechnical solutions through a committed, decolonizing, and careful dialog of knowledge. I call them bottom-up approaches. Once that is done, the article's second half derives ontological, epistemological, and political consequences from the conjugation of top-down and bottom-up approaches. Such consequences challenge some established or not yet entirely overcome understandings in the philosophy of technology (PT) and, in so doing, are meant to represent some steps in PT's decolonization. Even though both top-down and bottom-up approaches are considered, the article's main contributions are associated with (bottom-up) decolonial technical design practices, whose methodologies and outcomes are important study cases for PT and whose practitioners (i.e., decolonial designers) can be taken as inspiring examples for philosophers who want to decolonize/enlarge PT or make it decolonial (that is, a way of fostering decoloniality).
\end{abstract}

Keywords Coloniality · Decolonial technical design · Ontology of technology and technical design - Epistemology of technical design · Politics and technical design · Decolonial philosophy of technology

Cristiano Codeiro Cruz

cristianoccruz@yahoo.com.br

Extended author information available on the last page of the article 


\section{Introduction}

Coloniality is a concept created by Anibal Quijano in the late 1980s and early 1990s (Quijano, 1992; Mignolo, 2012, p. 2) that is fundamental to the decolonial reflection he inaugurated, systematized, or actualized. Since then, such reflection was vastly advanced, being also deployed and improved outside Latin America and the peripheral countries (Maldonado-Torres, 2008), and being incorporated into different academic areas, from design and innovation (Ansari, 2019; Cruz, 2021a; Jimenez \& Roberts, 2019; Keshavarz, 2020; Mohamed et al., 2020; Schultz et al., 2018) to philosophy (Ansari, 2018; Dussel, 2012; Estermann, 2014; Hui, 2016; Cruz, 2021b, forthcoming).

This paper aims to further a discussion already initiated or sketched elsewhere (Cruz, 2021b, forthcoming), (1) identifying steps and hypotheses concerning the decolonization-or decolonial enlargement_of the mainstream philosophy of technology (PT) and (2) discussing how to make PT actively decolonial. As in the above-mentioned previous works, the article's main contribution is widening and deepening critiques and tentative decolonial pathways to established PT based on what can be learned from decolonial engineering, architecture, and design practices. I call such an approach bottom-up decolonization of $P T$, as it starts from how technical $^{1}$ development is already manifesting itself today, even if only marginally and mainly in the peripheries, and from what can be learned from grassroots or (other) marginalized groups.

In addition to that, a dialog will be tried with decolonial initiatives of PT, such as Hui's (2016, 2017) and Ansari's (2019). They do not start from the empirical manifestation of technical production and grassroots people's knowledge, but from philosophy and scholars, thus proceeding through a non-empirically informed reflection, which is taken as a necessary condition for conceiving and constructing new cosmotechnics (Hui, 2016, 2017) or decolonial designs (Ansari, 2019). I call such an approach top-down, as it starts with reflection and theory all the way down to empirical technical constructions and design practices.

Despite that distinction, bottom-up and top-down decolonization of PT can be made complementary. Incorporating the latter here, even only with a supporting role, seeks to make more robust the point concerning the decolonization of PT. Either way, and for this paper to be grasped as it was meant to, its central concern is what we can learn from decolonial designs and how PT can support design teams to improve and multiply their decolonial interventions and sociotechnical constructions. Hence, decolonizing PT is necessary so to help us understand better and

\footnotetext{
${ }^{1}$ Unless where it is explicitly stated otherwise, the nouns "technology" and "technique" are taken as a synonym, referring to material or non-material technical solutions both pre-modern and modern or Western and non-Western. The same holds for the adjectives "technological" and "technical." With that option, it is not being argued for the complete indistinction concerning, for instance, modern and premodern technology. However, as will be shown, sociotechnical solutions like those produced by Brazilian popular engineering, which conjugate technical-scientific and traditional/grassroots knowledge in the technical solution and the very engineering approach, seem to significantly blur some clear-cut distinctions, like that one which associates (modern Western) "technology" with science (only).
} 
critically decolonial designs and sociotechnical solutions. Further, it can also enlarge our philosophical comprehension of technology and design, liberating us from its colonial imprisonments. However, to support and foster decolonial interventions, decolonizing PT should also make PT decolonial, actively advancing decoloniality. In sum, and paraphrasing Marx, this article intends to contribute to widening our philosophical understanding of technology and technical design in order to increase the potential of decolonial interventions and sociotechnical constructions to change the world.

In what follows, the paper is divided into four parts. Part one presents some definitions and theoretical bases concerning the (strand of the) decolonial reflection that substantiates this work. In part two, the characteristics of decolonial designs or sociotechnical solutions (so to achieve/promote decoloniality) are discussed, Hui's and Ansari's top-down decolonial proposals are presented, as well as the necessity of bottom-up approaches to achieve decoloniality and four examples of them (from engineering, architecture, and programming). Part three draws on the previous ones to discuss what it could mean to decolonize PT, focusing on three main areas: the ontology of technology and technical design; the epistemology of technical design; and politics concerning sociotechnical (decolonial) design and PT. Finally, part four recalls the article's central points and proposes how PT can become decolonial.

\section{Coloniality and Decoloniality}

Colonialism is the ideology that both justified or legitimized colonization and was produced by it, i.e., by the military occupation and economic and cultural subjugation of American, African, and Asian territories and peoples by European nations (Estermann, 2014, p. 3). Two central constructions to colonialism are race-to make evident the colonized's supposed natural inferiority and their need to be ruled and educated by the Europeans - and the destruction, denial, or disregard of native knowledge, which Santos (2016) calls epistemicide (Nhemachena \& Matowaniyka, 2020; Quijano, 1999; Santos, 2016). In Foucault's terms (1980, 2000), colonialism operates as the regime of truth or episteme of this particular articulation of power that conjugates the colonial system and capitalism. It arises as a construction of such power arrangement that also supports it (justifying and legitimizing it) and interdicts or makes it much harder to conceiving or theoretically supporting other power arrangements (given the natural inferiority of both the colonized and their knowledge, ways of knowing, worldviews, and values).

"Coloniality" refers to "power relationships and conceptions of being and knowing" (Maldonado-Torres, 2009, p. 685) that continued such subjugation even after the colonies' independencies. ${ }^{2}$ This way, if colonization was first (militarily) imposed onto the colonized, colonialism's success (with the help of local elites, for sure) produced coloniality as the internalization, acceptance, and active reproduction

\footnotetext{
${ }^{2}$ Which, as known, took place in the late XVIII and early XIX centuries in the Americas and after the World War II in Africa and Asia.
} 
of colonial subjugation. Then, even though colonization and colonialism can be taken as almost entirely overcome nowadays, coloniality is still in place, nurtured by "economic imperialism, symbolic and mediatic occupation, philosophical anatopism [i.e., mimesis of Western philosophy], and cultural alienation ever more subtle" (Estermann, 2014, p. 3). Indeed, the hegemonic status quo (1) interdicts alternative economic arrangements to neoliberal globalization with the help of local and foreign governments, institutions (like the World Bank and the International Monetary Fund), and military forces either from the central countries' armies or all types of mercenaries and armed groups; (2) imposes (or sells) the individualistic, JudeoChristian, democratic (whatever one means by that), universal "Western way of life" through all sorts of means from movies, songs, and TV shows to news, propaganda, and military intervention; and (3) acknowledges, legitimizes, or supports only the Western philosophical and technoscientific knowledge, ways of knowing, and problems through funding restrictions, academic accreditation requirements, honorific prizes, academic journals' editorial options and peer review processes, etc.

As can be seen, coloniality manifests itself in three main domains-(politicaleconomic) power, knowledge, and being. Such domains rely upon and reinforce one another. Indeed, the current hegemonic power arrangement, which conjugates neoliberal globalization and authoritarian or (weakly) democratic governments, demands and supports individualistic, de-territorialized (or Westernized), and resilient human beings, as well as the decontextualized technoscientific knowledge aimed at producing control and subjugation of both human beings and the environment. Likewise, such identities are products and producers of the hegemonic episteme or regime of truth, which tends to present every other worldview and value as inferior forms of the human highest possible realization (i.e., Western universalized identity), decrying non-Wester knowledges and ways of knowing (which are necessary for justifying and bringing about these other possible identities and worlds) as merely beliefs, ignorance, or backwardness.

In sum, thus, such triple coloniality allows for the maintenance of the disempowering, oppressive, and environmentally non-sustainable neoliberal and globalized status quo through the colonization of the dominated's imaginary and identity and the cancelation or neglect of knowledge, ways of knowing, and worldviews different from the hegemonic ones (Quijano, 1992, 1999; Ansari, 2018).

To succeed, decoloniality or decolonial/decolonizing movements or initiatives must challenge power, knowledge, and being as they are shaped by coloniality. In so doing, decoloniality does not mean the neglect or cancelation of Western products or achievements but their enlargement and possible pluralization. That would lead us to a plurality of ways of knowing, being, and acting/doing, that is to say, to the Zapatist "a world in which many worlds would coexist" (cf. Mignolo, 2011b). Such plurality is called pluriverse as opposed to the hegemonic, Western universal order (with its canonic power arrangement, legitimate knowledge and ways of knowing (episteme or regime of truth), and superior individual and collective identities) (Escobar, 2018). Similarly, decoloniality usually not stands for returning to any previous ethnic supposed golden age or for any ethnic purity. Instead, it proposes an intercultural dialog that could help subjugated cultures (critically) actualize themselves while being actively recovered and valued (Estermann, 2014). 
It can be said that coloniality and decoloniality have a lot to do with technological or sociotechnical imaginaries. As used by Sutz (2021), these imaginaries can be identified with two different sets of understandings: first, with how [Western, capitalist] technology is seen in general, as, for instance, the solution for all our problems, even the side-effects of previous technologies, or as the source of the main troubles we have, and second, with internalized collective understandings such as "we Uruguayan are incapable of developing proper science or technology," or its opposite, "we Americans can solve whatever techno-scientific challenge we might face." The point in the latter is that, once internalized, these imaginaries become self-fulfilling prophecies. Concerning the former, the hegemonic imaginaries provide general guidelines for a technological development that builds a sociotechnical order that only reinforces coloniality. Jasanoff (2015a) articulates and elaborates both sets of understandings, defining sociotechnical imaginaries as "collectively held, institutionally stabilized, and publicly performed visions of desirable futures, animated by shared understandings of forms of social life and social order attainable through, and supportive of, advances in science and technology" (p. 4). It can thus be argued that there is a colonial sociotechnical imaginary, the hegemonic one, which presents itself as universal (or superior) and imposes itself everywhere, as well as many possible decolonial ones, which a way or another must be fought for though. Overcoming coloniality also means building and fostering other sociotechnical imaginaries. ${ }^{3}$

At any rate, decoloniality points towards dreaming and co-constructing this pluriverse, these other possible worlds from the bottom-up, the subjugated, those made subalternate. It thus preconizes not only recovering and valuing their ancestor and constructed/improved knowledge, values, and worldviews but also empowering or emancipating these people/groups, or, in Freire's (2005a) words, supporting them in their "being more fully human." In other words, decoloniality acknowledges that other power arrangements, knowledges (or regimes of truth), and identities are possible; all this can be achieved through either incremental subversions or enlargements of their current hegemonic forms or somewhat radical ruptures concerning them; such subversions or ruptures must be informed or inspired by non-Western power arrangements, knowledges, and identities; the most oppressed can emancipate themselves and are the best candidates for the efficient cause of the construction of this pluriversal order, for they are, among other things, those who enjoy the least the goods of Modernity (or Western, capitalist hegemonic order) and, in many cases, also those least Westernized (concerning their identities and knowledges). ${ }^{4}$

\footnotetext{
3 That is precisely what a decolonial approach to technical design like popular engineering tries to do (see Sections 3.2.1 and 4.3 below).

4 Ansari identifies these potential decolonial guides with "the ex-colonized (i.e., new, hybrid subjects that so eagerly embrace globalization); the extra-colonial (i.e., those rare Indigenous peoples that live on the outskirts of the world-system and tenaciously preserve ways of being that have otherwise died out in the world); and the subaltern castes (i.e., those who have been "left behind" by modernity, never sharing in the privileges and spoils of becoming modern while nevertheless forming the living reserve that fuels the mechanisms of the neocolonial world-system)" (Schultz et al., 2018, p. 84).
} 
For all that to be accomplished, decoloniality and the decolonial processes that foster it presuppose care, openness, and commitment from those who want to take part in it. As for care, along with authors such as Bellacasa (2017), three articulated dimensions are considered: labor/work, affect/affections, and ethics/politics. In the decolonial design approaches presented later in this paper, care will be enacted as an ethical-political commitment to the supported/partner group's emancipation and more fulfilled life, to whose sociotechnical consecution it is essential to take care of the group (labor/work) and build with them affective bonds.

Such threefold caring enactment will allow for nurturing trust relationships and establishing a genuinely horizontal and wide exchange of knowledges, from procedure knowledge (related, for instance, to how to perform some task, organize the collective life, and produce or access knowledge) to values and worldviews. That is done both verbally and non-verbally, through words and arguments (sometimes also structured according to non-Western rationalities or logics) ${ }^{5}$ as well as through affection, social rituals, and body signs or movements. This vast knowledge exchange is called (broad) "dialogue of knowledge."

As a caring process committed to the group's emancipation, decoloniality is the opposite of paternalism, of doing for or in the place of the colonized/oppressed/ subalternate. Ultimately, emancipation means no longer controlling or tutoring the emancipated's acts or decisions, even when they might seem wrong or inappropriate to someone else (say, the philosopher or social scientist). As such, though, both decoloniality and emancipation are ideal horizons to which one (or a decolonial design team) can get closer, but whose building pathways can always be tricky. It is possible to identify eight empowering dimensions of sociotechnical interventions and five aspects of the supported/partner group's emancipation. These two sets of dimensions/aspects, which are developed later in this paper, can offer decolonial design teams additional (and somewhat more objective) evaluative tools for their interventions not to become simply different, non-hegemonic types of domination.

\section{Decolonial Technology or Technical Design}

Since technology and technical design do have politics (Winner, 1986) being, to a certain extent, shaped by society (i.e., by the ethical-political values and interests of the strongest stakeholders present in the design process) and, conversely, shaping society (Feenberg, 2010, 2017), they can arguably be colonial or decolonial. One example of the colonial approach to technical development can be found in the innovation movement articulated around initiatives like innovation hubs (Jimenez $\&$ Roberts, 2019). More generally, though, whenever technology and design do not challenge the technocratic, disempowering, socially unfair, environmentally nonsustainable, etc. status quo, it is colonial. It is not difficult to see that this is the rule, not the exception, in mainstream engineering, architecture, and design.

\footnotetext{
${ }^{5}$ See, for instance, Estermann (2004, chaps. 4 and 5).
} 
On the other hand, every time that technology or technical design helps or allows for decoloniality to advance-say "facilitat[ing] a process of de-linking [i.e., autonomization concerning colonial standards of power, being, or knowledge] and redirection into other modes of being/becoming" (Schultz et al., 2018, p. 81) or "be[ing] creatively reappropriated by subaltern communities in support of their struggles to strengthen their autonomy and perform their life projects" (Escobar, 2018, p. xi)—it is decolonial.

There are at least two ways of trying to decolonize technology and technical design. One of them presupposes a spiritual/intellectual liberation for designers or those who may have a central role in the design process as a pre-condition for this type of decoloniality to take place. Yuk Hui's and Ahmed Ansari's are examples of such approaches, which are sketched in the next section. The second way of decolonizing technology and technical design does not start from concepts and philosophy in a top-down manner as the first one. Instead, it draws on different possibilities of engaging with usually marginalized/oppressed/subalternate groups and individuals in a liberating or decolonizing process for all involved. From that process, it is expected to arise both decolonial sociotechnical solutions (i.e., technologies) and decolonial technical design approaches. Since it starts from praxis, the empirical, and a broad dialog of knowledge with the supported/partner groups, this way of decolonizing can be called bottom-up. It is presented in the last section of this part.

\subsection{Hui's and Ansari's Top-Down Proposals}

Central to Hui's reflection is the concept of cosmotechnics, which he defines as

[s]cientific and technical thinking emerges under cosmological conditions that are expressed in the relations between humans and their milieus, which are never static. For this reason, I would like to call this conception of technics cosmotechnics. One of the most characteristic examples of Chinese cosmotechnics, for example, is Chinese medicine, which uses the same principles and terms found in cosmology, such as Yin-Yang, Wu Xing, harmony, and so on, to describe the body. (Hui, 2016, p. 18)

Taking technology as affiliated to some cosmotechnic (and supporting cosmology) like the capitalist one adds a new layer to-or make evident the presence of this component in-the already established understanding that acknowledges technology's social or cultural nature (in addition to its instrumental and epistemic ones). In so doing, Hui concedes that Heidegger's enframing (Gestell) is a reality in modern technological order (Hui, 2016, p. 228) but (1) identifies it with one specific cosmotechnics, the modern Western, capitalist one (Hui, 2016, p. 228) and (2) proposes that overcoming such an order is within our reach, depending on recovering different cosmotechnics developed by humankind and, based on that, trying new cosmotechnics and respective new supporting cosmologies (Hui, 2016, p. 229, 289, $310 ; 2017$, p. 336-7). That would make us aware that we may invent technology 
but are also conditioned by it. ${ }^{6}$ It is not to be aware of it that makes us fall prey to enframing (Hui, 2016, p. 228).

Since Western cosmotechnic was imposed worldwide through colonization and coloniality, recovering ancestor cosmotechnics and, with that, becoming aware of us being conditioned by technology and trying new cosmotechnics attuned with our time is a process of decolonization (Hui, 2017, p. 336-7). At any rate, what is aimed is not to return to nature or any sort of ethnic purity, but to develop a future different from the repetition of the enframing and colonial present, starting, however, from our present reality and all that technology allows us to do, be, and know (Hui, 2016, p. 240-1; 2017, p. 325-6).

Hui thus proposes that we reappropriate modern technology (instead of refusing or discarding it) in order to create different cosmotechnics (from the capitalist and enframing hegemonic one) and, with that, be able to substantiate other cosmologies (different from the individualistic, dualistic, not caring, etc., which is the hegemonic one). As such, his proposal is decolonial because it works as a way of both overcoming the enthronization (or unconscious repetition or reproduction) of modern Western cosmology and conceiving and implementing new possible ones (through the development of adequate cosmotechnics).

For all that to be possible, it is necessary to "undertak[e] a metaphysical and historical project" (Hui, 2016, p. 261), "re-opening [...] the question of technology through the affirmation of non-modern cultures" (Hui, 2017, p. 337). Only then, new cosmotechnics and supporting cosmologies (or possible worlds) will be imaginable. Thus, liberation or decoloniality is a consequence, first and foremost, of spiritual or intellectual enlightenment or cultivation of an intellectual elite (say, the philosophers) who can then offer it to, or share it with, designers (who will probably have to supplement it with new, enlarged, or more appropriate knowledge) ${ }^{7}$ (Hui, 2016, p. 296, 307, 310). From that moment on, new cosmotechnics become possible again, and the decolonial pluriverse can be (re)inaugurated (or can replace the universal modern Western, capitalist, and colonial one). ${ }^{8}$

\footnotetext{
${ }^{6}$ In Arturo Escobar's words, “[...] every tool or technology is ontological in the sense that, however humbly or minutely, it inaugurates a set of rituals, ways of doing, and modes of being (Escobar 1994). It contributes to shaping what it is to be human. A second sense in which design is ontological, already hinted at by Winograd and Flores, is that, in designing tools, we (humans) design the conditions of our existence and, in turn, the conditions of our designing. We design tools, and these tools design us back. [...] As I jokingly say, paraphrasing, "give me a[n Amazonian indigenous longhouse,] maloca, and I will raise a relational world" (including the integral and interdependent relations between humans and nonhumans); conversely, give me a suburban home, and I will raise a world of decommunalized individuals, separated from the natural world. Design thus inevitably generates humans' (and other Earth beings') structures of possibility" (Escobar, 2018, p. 110-111).

7 "The reappropriation of modern technology from the standpoint of cosmotechnics demands two steps: firstly, as attempted here, it demands that we reconfigure fundamental metaphysical categories such as Qi-Dao as a ground; secondly, that we reconstruct upon this ground an episteme which will in turn condition technical invention, development, innovation, in order that the latter should no longer be mere imitations or repetitions." (Hui, 2016, p. 307)

8 "The concept of cosmotechnics - beyond cosmologies - therefore hopes to reopen both the question and the multiple histories of technology. In other words, in using China as an example, and proposing to take up the $Q i$-Dao cosmotechnics as the ground and constraint for the appropriation of modern technology, we aim to renew a form of life and a cosmotechnics that would consciously subtract itself from
} 
Ansari's proposal also relies on theoretical enlightenment or liberation as a precondition for decolonial design. As Hui, he defends decolonizing history and philosophy of technology as a way to overcome modernity's universal way of knowing and being and (re-)establish pluriversality (Ansari, 2018, p. 5-6). Instead of proposing a concept like cosmotechnics, he defends that "We first need an account of the artificial and of the condition of artificiality, an account which can explain the different sociotechnical trajectories that various civilizations exhibit up until modernization through colonialism and globalization" (Schultz et al., 2018, p. 84) and that "as designers committed to decoloniality, we must not accept that there is only one form of technicity, that which belongs to the West" (Ansari, 2018, p. 6).

Two differences concerning Hui's ideas are worth highlighting in Ansari's proposal. The first and more subtle one is that, despite preconizing intellectual cultivation or enlightenment as a necessary condition for decolonial design, the historical and philosophical journey he sketches is expected to be undertaken also or primarily by designers. So, his top-down approach starts from a "top" that is one step closer to design practice or technology development than Hui's departure point (i.e., philosophers). The second difference has to do with the sources for such a journey. If Hui mainly relies on written historical documents and the philosophers' professional skills, Ansari suggests that:

[t]his task cannot be undertaken solely through the lens of contemporary Western thought, even if this lineage of thought has problematized the very modernity it birthed. It must be thought through looking from the lens of the more marginal perspectives of: the ex-colonized (i.e., new, hybrid subjects that so eagerly embrace globalization); the extra-colonial (i.e., those rare Indigenous peoples that live on the outskirts of the world-system and tenaciously preserve ways of being that have otherwise died out in the world); and the subaltern castes (i.e., those who have been "left behind" by modernity, never sharing in the privileges and spoils of becoming modern while nevertheless forming the living reserve that fuels the mechanisms of the neocolonial world-system). To think beyond modernity from within modernity is not an easy task. But it is only when we incorporate these marginal perspectives into a reflection on the nature and history of modernity and of artifice to try and understand how it is that plural cultures were drawn into the binary of center and periphery, that we can then begin to tackle the productive task, from each of those peripheries, of designing plurally again. (Schultz et al., 2018, p. 84)

In other words, the designers' enlightenment demands their capability of viewing the modern world and technology through the marginalized's, subalternate's,

Footnote 8 (continued)

and deviate from the homogeneous becoming of the technological world. This is impossible without a reinterpretation of our tradition and its transformation into a new episteme. And it will also involve another form of translation: no longer a translation based on equivalence [...], but a translation based on difference, a translation that allows a transduction to take place. [...] Transduction, as understood by Simondon, implies the progressive structural transformation of a system triggered by incoming information [...]." (Hui, 2016, p. 310) 
or oppressed's lenses. Thus, regardless of such intellectual cultivation being something designers must undertake independently, they can only succeed in it if they learn with those left out (and different) forms of seeing the world. It is not through the analysis of ancestor cosmotechnics that we will be able to overcome modern enframing and coloniality, but by viewing the world through the lenses of actual living people, those who, differently from most professional philosophers, engineers, designers, or architects, are not (entirely) integrated into Modernity, enframing, or coloniality.

\subsection{Bottom-up Approaches to Decolonizing Technical Design}

Top-down proposals to decolonizing technical design and technology take decolonizing the minds of philosophers, engineers, designers, architects, and other central stakeholders to the design process as a pre-condition for developing decolonial technologies and technical design approaches. In so doing, however, they do not directly or ostensibly incorporate those who suffer the most the harmful consequences of Modernity, the poor, marginalized. For sure, decolonial technologies and technical design practices are supposed to help decolonize these people's imaginaries and emancipate/empower them. Yet, that is a step forward that such proposals do not address directly.

Bottom-up initiatives are meant to deal with all that-decolonizing and empowering/emancipating the poor and the intellectual elites (i.e., philosophers, designers) - at once. They try to accomplish this through an honest dialog of knowledge (meant as this broad, horizontal, and caring exchange of knowledge verbally and non-verbally) between the technical team and the supported/partner group (usually of grassroots, marginalized, or native/traditional people) and empowering design practices. Let us start with the latter.

Technical design can be empowering in at least eight different, though complementary, ways (cf. Kleba \& Cruz, 2021): (1) fostering sociotechnical inclusion, i.e., assuring the fundamental conditions for a human existence deemed dignified by the supported/partner group or the technical team; (2) valuing cultural difference, i.e., acknowledging and supporting plural ways of life, with their correspondent knowledges, ways of knowing, worldviews, and values, actively transforming the design process to incorporate them and thus build sociotechnical solutions (more) appropriated to the group; (3) nurturing qualitative relationships, i.e., strengthening the relational basis for structural change, building trust and mutual respect, caring for each other, and establishing affective bounds among the group's members and between them and the technical team; (4) sharing technical competencies, i.e., technical knowledge that can make the group autonomous or less dependent on technical support from others (say, for operating and maintaining the sociotechnical solution built in the intervention process) and more capable of improvising and autonomously building their own solutions; (5) practicing investigative methodologies, i.e., sharing and training knowledge, skills, and competences related to the construction of knowledge and self-organization; (6) promoting social and economic emancipation, which has to do with, among other things, allowing/encouraging the community to 
identify its social and economic issues and addressing them according to its talents, needs, and desires; (7) cultivating political emancipation, which has to do with, among other things, encouraging the group to develop their political potentials and build strategic alliances with other social actors; and (8) growing environmental awareness (concerning the ecological pre-conditions for the human life to thrive on Earth, the relational and interdependent condition of our life as living beings, and/or the ontologic equity or dignity of non-humans) and encouraging the group's ability to conceive and construct sociotechnical solutions that materialize or support such awareness.

For achieving the highest decolonial results, a technical design should organically address more of these eight dimensions (intervention density) and do so with care and much critical sense (intervention quality). All this presupposes a close, committed, and open relationship between the technical team and the supported/partner group. As seen earlier, that is the basis for a genuine dialog of knowledge to be established between them, through which both parts will be able to teach and learn from one another.

This way, the decolonial impacts of a technical design might be dismembered into five entangled aspects (which are separable only analytically) (cf. Cruz, 2021): (1) Quality of life: how or to what extent did the supported/partner group's material life conditions improve due to the technical design undertaken? (2) Ontology or worldview: how or to what extent did the group become (more) aware of the worldview and ideals they have or might find worth pursuing and of sociotechnical solutions able to support or foster them? (3) Awareness or critical sense: how or to what extent did the actors involved in the technical design grow more aware of the contingent character of the injustices and oppressions in place in their reality and of the structures of power that produce or support them, as well as more capable of criticizing such order and any inherited, constructed, or imposed narrative, value, ideal, knowledge, identity, or worldview? (4) Dialog of knowledge: how or to what extent did the technical intervention process (a) allow for the active recovery of the local group's knowledge? (b) undertake a mutually beneficial broad dialog of knowledge that enlarged all the involved actors' ability to know, be, and do? (c) make the construction of a sociotechnical solution that incorporated the local group's knowledge possible? (d) allow for the change or widening of the intervention approach due to such dialog of knowledge? (5) Agency: how or to what extent did the actors involved in the technical design increase their power or capacity of agency, of articulating with other actors and being (part of) the efficient cause of the change they want to see in their reality?

Many technical design practices aim to be or can be called decolonial. In the remainder of this section, four of them are sketched. ${ }^{9}$

\footnotetext{
${ }^{9}$ For a more detailed analysis of the decolonial impacts of the three first cases (Brazilian popular engineering and Colombian and Brazilian participatory design examples), see Cruz, 2021a and Cruz, 2021.
} 


\subsubsection{Popular Engineering}

Popular engineering (PE) is a Brazilian initiative that arises in the mid-2000s, conjugating three main elements: solidarity economy ideals of self-management, cooperation, and solidarity; social technology perspective of co-design (or co-construction), local solutions, re-application, and emancipation/liberation through the design process; and intervention promoted by university extension centers or autonomous collectives of popular engineers (Cruz, 2020, 2021a, forthcoming; Fraga et al., 2020).

$\mathrm{PE}$ is currently practiced by twelve extension centers, some isolated individuals, and a couple of collectives in 26 universities, counting with about 300 practitioners (from engineering and other areas), gathering hundreds of students in its annual national and regional meetings (Araújo \& Rufino, 2021). Its interventions usually focus on assisting social movements and deploy methods that conjugate action research and popular education. The co-constructed sociotechnical solutions PE brings about range from process management to labor artifacts or machines, which are appropriations (or different types of sociotechnical adequacy (Dagnino et al., 2004)) of conventional solutions that incorporate the supported/partner group's knowledge, values, and worldviews (Cruz, 2020, 2021a, forthcoming; Cruz \& Rufino, 2020; Araújo and Rufino, 2021).

The intended/established dialog of knowledge between the technical team and supported/partner group is a process based on Freire's popular education ideals and procedures (Freire, 2005a, b; Freire \& Shor, 1987). Such dialog is supposed to allow for co-designing the best possible sociotechnical solution; help liberate/empower/ decolonize both the supported/partner group and technical team; and contribute to the improvement of the intervention/design approach. For that to be achievable, PE teams see care as affective bonds, taking care (labor/work), and commitment to the group's situation, needs, and political struggles as fundamental for their intervention. This way, PE is inseparable from knowing the group and socially interacting with them, becoming friends, and fighting their fights (Cruz, 2020, 2021a, forthcoming; Araújo et al., 2019, chap. 1 and 2).

\subsubsection{Emancipatory Participatory Design}

The participatory design (PD) tradition arises in Scandinavia in the 1970s, aiming to empower the workers and democratize the informatization process that many companies started to undertake (Robertson \& Simonsen, 2013). Since then, PD has been applied in multiple technical design areas and contexts (besides the labor one) and has significantly improved and consolidated its methodologies and procedures (Van der Velden \& Mörtberg, 2015; Bannon \& Ehn, 2013; Robertson \& Simonsen, 2013). Of particular importance to decoloniality are the emancipatory PDs (Robertson \& Simonsen, 2013). Two Latin-American examples of them are briefly discussed below, one from Colombia and the other from Brazil.

The Colombian initiative is a one-off approach applied in a Master's capstone project on computer system engineering. It was developed alongside a group of traditional embroiderers from Cartago city, counting, in the technical team, with two engineers and two ethnographers, in addition to Laura, the student 
responsible for the project (Rivera et al., 2016; Cortés-Rico \& Piedrahita-Solórzano, 2015).

Prior to its contact with the embroiderers, the technical team's original idea was to automate this specific embroidery these embroiderers did, called calado. However, once it knew the caladoras (as these embroiderers are called) and lived and worked with them in a couple of periods of immersion, it realized that automation was not in the interest of the caladoras. Doing calado was not a burden for them, as it was an opportunity for them to interact with one another and take care of themselves. Plus, once calado was automated, the caladoras would run the risk of being replaced by some embroidery machine (Pérez-Bustos, 2017; Pérez-Bustos \& Márquez, 2016; Rivera et al., 2016; Cortés-Rico \& PiedrahitaSolórzano, 2015).

The co-designed final solution was a tangible user interface that allowed the caladoras to try new patterns before doing them in the fabric (calado is an embroidery that cannot be undone) (Rivera et al., 2016; Pérez-Bustos \& Márquez, 2016). Assuring the caladoras central role in the design process and Laura learning the rudiments of calado proved fundamental for enlarging (or modifying) the caladoras' and Laura's labor potentials. In Laura's words:

Configuring the project to give responsibility to users was important in order to make sure that the designed technology would have a real impact and would lead to new ways of conceiving the practices both of making embroideries and of designing technology. (Cortés-Rico \& PiedrahitaSolórzano, 2015, p. 520)

For that to be possible, affective bonds and non-paternalistic care were essential (Pérez-Bustos, 2017; Pérez-Bustos and Márquez 2016).

The Brazilian participatory design in question is called Terceira Margem (Third Margin) (TM). It is a collective of architects created in 2013 whose specificity is aggregating to PD the sensorial stimulation of the inhabitants that demand the design. By doing that, TM intends to activate the inhabitants' body sensations and feelings and help them access their unconscious minds. Once that is achieved, the coloniality of imagination is (or can be) overcome, and different forms of inhabiting our world can become conceivable (Guizzo, 2019, 2021).

After all, what world do we want to inhabit? That is the central question of TM's designs. This question is thought about while we dance in circles for activating the unconscious mind and escaping an answer that, at first, can also be colonized. We believe that the circle and other "enchanted" practices can create what we call real design demand, valuable bridges with the territory and its inhabitants before the first sketches are made. (Guizzo, 2019, p. 26)

As in the previous cases, care is something essential here too. Further, TM's methodology is not only procedurally unique concerning how architectural design is commonly done, it is also intended to equip the architect(s) in charge of sketching the sociotechnical solution, who happen(s) to be the one(s) that conduct(s) the 
sensorial workshops, with insights they are given by the inhabitants' responses to such stimulations. Hence, both the final solution and design process are (at least partially) shaped by the inhabitants' (decolonial) contributions through a well-prepared process of sensorial and image- or narrative-based dialog of knowledge that incorporates elements from the inhabitants' unconscious mind (Guizzo, 2019, 2021).

\subsubsection{Decolonial Al}

For decolonial AI, it is considered the proposal of Mohamed, Png, and Isaac (2020), who compile different and complementary approaches to AI that are expected to be, or can be used as, decolonial. In so doing, they aim to help create a "decolonial field of artificial intelligence" (p. 659) that "align our research and technology development with established and emerging ethical principles and regulation" while "empower[s] vulnerable peoples" (p. 663). For doing so, three tactics are proposed: creating a critical technical practice of AI; seeking reverse tutelage and reverse pedagogies; and renewing affective and political communities.

Critical technical practice means "a self-reflexive approach to developing and deploying AI that recognizes power imbalances and its implicit value systems" (Mohamed et al., 2020, p. 672). It is developing AI algorithms in a reflexive, critical way that "uncovers hidden assumptions and alternative ways of working" (idem, p. 672). For that to be accomplished, the authors understand that five aspects should be observed in such a practice: algorithmic fairness, AI safety, equity and diversity, policy-making, and AI as a decolonizing tool (idem, p. 673).

Reverse tutelage and reverse pedagogies are related to learning from, or being taught by, the peripheries and vulnerable people AI designers might be working for (or with) (Mohamed et al., 2020, p. 674-5). It is a way of overcoming Santos' (2016) epistemicide, thus enlarging what AI can design and how far it can go in its decolonial search. "Deciding what counts as valid knowledge, what is included within a dataset, and what is ignored and unquestioned is a form of power held by AI researchers that cannot be left unacknowledged. It is in confronting this condition that decolonial science, and particularly the tactic of reverse tutelage, makes its mark." (Mohamed et al., 2020, p. 675).

Renewed affective and political communities refer to both this decolonial (or another possible) world sought and the efficient cause for it to be brought about. Two main pathways for achieving it are available here, and both aim at fostering solidarity for overcoming or reforming "systems of hierarchy, knowledge, technology, and culture at play in modern life" (Mohamed et al., 2020, 676): (1) incorporating decolonial tools into regular AI design and (2) associating oneself with already existent grassroots organizations (idem, p. 676).

Operationalizing this critical practice will require not only foresight and case study research, but also approaches that support new research cultures, along with innovative technical research in domains such as fairness, value alignment, privacy, and interpretability. Moreover, there is a strong need to develop new methodologies for inclusive dialogue between stakeholders in AI devel- 
opment, particularly those in which marginalized groups have meaningful avenues to influence the decision-making process, avoiding the potential for predatory inclusion and continued algorithmic oppression, exploitation, and dispossession. (Mohamed et al., 2020, p. 677)

This decolonial AI proposal is a work in progress, an approach not yet deployed as such anywhere. Either way, it highlights three aspects that are also central to the other three decolonial practices to the technical design presented: a critical analysis of the mainstream approach to design in each area (e.g., engineering, architecture, and programming) that leads to procedural/methodological changes; supported/ partner groups being assured central role in the design process, which, among other things, usually allows them to teach how engineers, architects, and designers can improve their decolonial approaches and disciplines; and actively trying to construct or support a different form of life as both the design intended goal and the (efficient) pre-condition for it.

\section{Decolonized Philosophy of Technology}

As seen, decoloniality stands for overcoming the coloniality of being, knowledge, and doing. In the realm of technology and technical design, decoloniality can be promoted or tried by at least two different general approaches. One of them starts from philosophy and concepts down to technology and design (top-down). The other learns with marginalized or grassroots people and contributes to these people's emancipation or decolonization, building theorizations out of these processes (bottom-up).

Decoloniality presupposes the empowerment or emancipation of the "most" colonized too, say, the $50 \%$ that face the harshest life conditions or social segregation/ stigmatization. That is why top-down approaches may fall short in their achievements, for they may not go much further than allowing the elites (e.g., philosophers, engineers, architects, and designers) to conceive and construct sociotechnical orders good for them but not necessarily for the $50 \%$. The pluriversal order that decoloniality seeks cannot be constructed for the (most) oppressed. It has to be constructed with them.

However, top-down decolonization can help at least part of those involved in bottom-up technical designs (e.g., engineers, architects, programmers, and social scientists) to improve it. In this sense, it can be said that such approaches are or can be complementary. How such complementarity can be constructed is highlighted later. In the remainder of this chapter, ontologic, epistemic, and political consequences will be drawn from this dialog with bottom-up and top-down approaches to decolonizing technology and technical design and rendering them decolonial, i.e., making them capable of fostering decoloniality. That is meant to help decolonize philosophy of technology (PT) and make it decolonial. Before turning to it, though, let us synthesize the decolonial traits of the four bottom-up practices sketched before. 
For being decolonial, a technical design must have some positive impact concerning the supported/partner group's quality of life, critical sense, and agency, which presupposes some degree of (a broad) dialog of knowledge and the group becoming more (critically) aware of their knowledge and values, ideals, and worldview. By contrast, the technical team improves its critical sense and learns how to ameliorate its decolonial design methodology and think of, and help sociotechnically design, other possible worlds.

The particular way each of the four presented practices fulfills these aspects and the degree to which they do so may vary significantly. Part of such diversity was analyzed elsewhere (Cruz, 2021; Kleba \& Cruz, 2021). However, for the reflection to be developed in this part, it is enough to highlight the aspects that differentiate these technical designs from the mainstream ones, even though some of the analyzed practices might not present part of such features. They can be listed as follows:

a. Acknowledging and nurturing care (as labor/work, affect/affections, ethics/politics) as a technical design's non-negotiable dimension

b. Assuring the supported/partner group a central role in all phases of the technical design process

c. Recovering the group's knowledge, values, ideas, and worldviews to actively and critically incorporate them into the sociotechnical solution(s) to be built

d. Sharing with the group some technical or academic knowledge that can help them know, be, or do better (or differently)

e. Incorporating body stimulation and movements and the unconscious mind into the design

f. Encouraging the group to imagine other possible worlds (and their supporting sociotechnical imaginaries)

g. Acknowledging and cultivating the group's emancipation and political agency as a pre-condition for any decolonial sociotechnical order to be imagined and implemented

h. (Socio)technically co-constructing these other possible worlds (critically appropriating mainstream technology, or capitalist cosmotechnics, as Hui would put it)

i. Learning with the group and from the co-design process how to do better decolonial design (which encompasses improving the design methodology and enlarging or pluralizing some of the technical design supporting knowledge)

j. Operating ideally in inter-/multi-disciplinary technical teams.

\subsection{Ontology}

In this first section, what will be tried is enlarging, overcoming, or denouncing modern contingent assumptions concerning technology and technical design that still seem to be taken by many (most?) as the manifestation of their very essence.

Relationality At least as far ago as 1958's Simondon's Du mode d'existence des objets techniques, it is being sustained on philosophical grounds that technology has a relational nature. For Simondon, it means at least three complementary but 
different things: technology and its associated milieu shape and create one another (Simondon, 1989, p. 22-3; Barthélémy, 2014, p. 36, 48-53); technology mediates humans' relation with their environment (Simondon, 1989, 164); technology (or an invention) is a dialectical synthesis that mediates two hitherto irreconcilable situations, what was already technically possible to be done and that which, not being possible, presented itself as desirable to be so (Simondon, 2008, 139-44).

As developed elsewhere (Cruz, 2021), Feenberg (2017, chap. 3) proposed enlarging Simondon's associated milieu, incorporating social stimuli as legitimate technology's shaping elements. However, Feenberg failed to acknowledge other social stimuli than people's necessities, desires, and capabilities. An additional class of them encompasses structured procedures, imagery lexicon, and aesthetical values, which are part of the contents of Walter Vincenti's (1990) design instrumentalities. These elements might have a huge impact on conceiving and constructing the sociotechnical solution, as well as on shaping the design approach and designers' capacity to do decolonial design (Cruz, 2021).

Once technology's relational nature is thus additionally enlarged (concerning Feenberg's proposal), it makes more evident its sociotechnical and cosmotechnical essence. As explained below, such enlargement also unveils ways of further pluralizing (or decolonizing) technology and technical design, as well as the imperative of care.

Art of Engineering (or of Technical Design in General) As developed in detail elsewhere (Cruz, 2021), acknowledging the role of structured procedures, imagery lexicon, and aesthetical values in technical design seems to corroborate Ferguson's understanding according to which engineering (and technical design in general) could never be entirely rationalized, being, instead, a lot like art (Ferguson, 1992). Indeed, it is not only that such (to a certain extent) technical-scientifically arbitrary elements have an essential role in the design process and its outcomes. Their arbitrary pluralization can make possible or interdict certain sociotechnical solutions and design styluses (Cruz, 2021).

Understanding the nature of technical design this way is, on the one hand, a widening of a persistent and perhaps still dominant comprehension that intends to reduce design to some sort of science or entirely rationalizable approaches (Franssen et al., 2018; Wendt, 2018). ${ }^{10}$ Such enlargement makes it possible for this concept, "technical design," to encompass decolonial design. As a result, on the other

\footnotetext{
10 "Commercial [mainstream] design inserts a hyper-intentionality that mandates that designers predict the unpredictable. The so-called data-driven methods, rising popularity of A/B testing, analytics benchmarking, etc. are celebrated for their ability to create a (false) sense of security in inherently complex environments, and the illusion of certainty pervades the methods by which we design." (Wendt, 2018, p. 117-118) "This result [Arrow's theorem that implies that in most multi-criteria problems the notion of 'optimal' cannot be rigorously defined] seems to except a crucial aspect of engineering activity from philosophical scrutiny, and it could be used to defend the opinion that engineering is at least partly an art, not a science. Instead of surrendering to the result, however, which has a significance that extends much beyond engineering and even beyond decision making in general, we should perhaps conclude instead that there is still a lot of work to be done on what might be termed, provisionally, 'approximative' forms of reasoning." (Franssen et al., 2018).
} 
hand, it allows designers to learn possible ways of nurturing pluralization: engaging in a deep and honest dialog of knowledge as decolonial designers do. Indeed, it seems that the most significant impact on the design approach of the supported/ partner group's knowledge is precisely fostering the pluralization of structured procedures, imagery lexicon, and aesthetical values (Cruz, 2021).

From this enlarged point of view, engineering and other technical designs reveal themselves as less professional-only activities. Assuring the "users" (or supported/ partner group) a role not only in the so-called context of use and in the first steps of the design process but also in the, so to speak, more heavily technical design stages $^{11}$ as the described decolonial approaches do (Cruz, 2021b) can be positively disruptive. It might be liberating/decolonizing to users/supported groups perhaps as much as it can be to designers and designing itself.

Care As shown in the decolonial practices analyzed, care-as labor/work (of taking care of the supported/partner group), affect/affections (or affectively bonding with the group), and ethics/politics (or committing to the group's political struggles through the design process) - is not only reconcilable with technical design as it is fundamental for the decolonial impacts on both the supported/partner group and the design itself. It means that more than just strictly professional bonds between the technical team and the group do not necessarily subvert the technical process but, on the contrary, make it actually possible (concerning the decolonial sociotechnical order aimed at). As mainstream technical development does, not incorporating care into the technical design is not a necessary condition for technology to be produced but, arguably, for submitting everyone and everything to coloniality.

Technical Design and Decoloniality As Ansari puts it very clearly, "A decolonizing ontological framework must see design as a sociotechnical mechanism of inquiry, re-enunciation, and re-narration. It is a project of looking back and re-framing certain material practices, and also a project of understanding the relationality of things beyond their mere objecthood" (Schultz et al., 2018, p. 92). That can be achieved through a top-down or bottom-up approach, even though, as far as decoloniality is concerned, it is best implemented through a proper conjugation of them led by (or at the service of) the latter.

The point here is overcoming modern instrumentalist reduction of technical design, which strips design from values other than the modern and capitalist hegemonic ones (Feenberg, 2010, 2017). It has to do with acknowledging the design's relational, artistic, and caring nature, as well as its inevitable colonizing or decolonizing role. As Keshavarz (2020) critically presents concerning humanitarian design to refugees in Europe, technical design, taken and practiced as a merely (instrumental) problem-solving activity, keeps sociotechnically producing the same oppressive reality where disempowered and displaced people treated as refugees is an almost

\footnotetext{
11 That is to say, in van de Poel's (2009) stages two and four (conceptual design and embodiment design) in addition to stages one and three (problem analysis and formulation, and choosing one conceptual solution) (Cruz, 2021b)
} 
inevitable consequence (more about the critique to reducing design to problem-solving is discussed later.)

Further, resuming the dialog with Simondon, the point is about (1) reclaiming to design-or invention - the harmonization it is supposed to (or can) advance between human beings and the natural environment we inhabit (and co-shape) and, to a certain extent at least, also between different groups of human beings (Simondon, 1989, p. 164; 2009, p. 129); and (2) educating the poet-technicians capable of such designs/inventions (Simondon, 2009, p. 111-112).

As Jimenez and Roberts argue concerning innovations:

Future research should put this in action to see in what ways innovations/tech hubs can produce values of environmental ethics, collective benefits and a strong spiritual and affective rationality, thereby promoting an alignment with such worldviews. The inclusion of indigenous viewpoints (like Buen Vivir) should not just be instrumental, it should be epistemological and ontological. In our view, the Western (neoliberal) approach to innovation represents only one possible approach among others, and we should therefore accept the possibility of a plurality of legitimate paradigms around innovation and its impact in our societies. In this sense, in a world with increasing inequality, huge environmental and ecological risks, 'Is another innovation possible?' (Jimenez and Roberts, 2019, p. 189)

\section{Two Circumscribed Points}

(1) Very frequently, replication and scalability, as well as automation and industrialization, seem unwittingly taken as necessary signs of proper technical development (Ansari, 2018, p. 4). The same holds for Simondon's assumption concerning technical objects development, which would necessarily lead to standardization and technical networks (Simondon, 1989, p. 15-16; 2009, p. $108-110,112-113,122-123)$. Decolonial designs seem to problematize, in a way or another, all such assumptions. The question to be answered here is to what extent does modern capitalist technology enframe these understandings, making some philosophers and other thinkers essentialize aspects that are, instead, contingent manifestations of (Western) technology?

(2) Likewise, it is too common to find an association between technical advancement and the liberation of human beings of a supposedly necessarily meaningless or alienating work. Simondon essentializes that in the technical individual's natural imperative of increasing concreteness (Simondon, 1989, p. 116-9), which would liberate human beings from (so closely) operating the machine. In his humanistic understanding, such a natural or proper development of technical inventions could allow human societies to evolve culturally, constructing more meaningful and fulfilling activities or occupations for their members (Simondon, 1989, p. 
103-106, 230-231; 2009, p. 127-128; Barthélémy, 2014, p. 142-143). Simondon acknowledges that this change not always happens and attributes that to cultural hysteresis or delay concerning technical advances (Simondon, 2009, p. 127-128) or to us not knowing technology and its nature properly (Simondon, 1989, p. 126-128, 145-147), reducing it, for instance, to technocratic power generation (Simondon, 1989, p. 10).

Compelling as these arguments can be, it is still arguable that Simondon smuggles European/Western conceptions into his ontology of technology, essentializing aspects like work-saving that, on the one hand, is an imperative to capitalist search for control and maximizing profit, and, on the other, is by no means universally taken as a necessary good in itself. Works like those practiced by the caladoras are meaningful and fulfilling for them. The caladoras resist automating calado not because they suffer giving up the technical role they have in this embroidery, attached to a less fulfilling job or socially ascribed place from which they cannot liberate themselves, but instead because embroidering allows them to cultivate their bonds with one another and take care of themselves. In so doing, they nurture care and connection and the empowering existential and political role the latter might have in their lives.

Top-Down Contribution Up to here, all proposed ontological critiques, enlargements, or changes were at least partially informed by empirical data (even Feenberg's enlargement of Simondon's associated milieu). In this broader sense, they might be called bottom-up. Part of what was developed above can be identified as, or furthered by, Ansari's top-down proposal of looking at—and decolonizing - the history and philosophy of technology with the marginalized's eyes.

As for Hui's project of creating plural cosmotechnics (from the proper appropriation of the capitalist one), inasmuch as the decolonial approaches to the technical design presented effectively collaborate with co-constructing other worlds or sociotechnical orders, even if only locally, it might be said that they are producing other cosmotechnics. That does not mean that Hui's proposal becomes pointless. Developing it (1) can help decolonial designs improve (allowing, for instance, to further decolonize the designers' imaginary and the design disciplines); (2) provides different sources for pluralizing cosmotechnics like historical documents; and (3) permits to educate designers (from engineering, architecture, design, and other technical areas) from a more theoretical domain, not so closely associated with, and frequently deplored for being a, political action (as decolonial designs inevitably are, or are supposed to be). That is one first way of describing the potential complementarity of top-down and bottom-up approaches.

One last point that might be worth investigating concerning Hui's project of pluralizing cosmotechnics is if his historical-philosophical research of documented cosmotechnics can be complemented, or, sometimes, even replaced, by the type of discoveries and constructions produced by decolonial technical designs. 


\subsection{Epistemology}

The epistemological aspects of the decolonial critique, enlargement, or change made evident or defendable by the bottom-up and top-down approaches presented can be synthesized as follows.

In general terms, conceiving other sociotechnical orders or worlds, decolonial ones, demands a new episteme or regime of truth. Santos (2016) understands that this can be achieved through "cognitive justice," the opposite of the epistemicide promoted by coloniality. Cognitive justice is based on ecologies of knowledge and intercultural translation, of which the dialog of knowledge actively promoted by the decolonial approaches to the technical design presented earlier is a particular and compelling case. Underlying the imperative for cognitive justice is a double understanding: (a) every technical-scientific or political knowledge is to a certain extent situated, produced from some geographic, historical, sociological, and existential place; (b) every knowledge produced is incomplete, even Western science and technology, concerning to what is to (or can) be known and what is necessary for us to (be able to) conceive and construct other possible worlds.

Hui's decolonial approach focuses on learning from cultures different from the Western one. Ansari suggests revisiting the history and philosophy of technology with the lenses of, or from the place occupied by, the marginalized. The bottom-up approaches stand for a (liberating or decolonial) dialog of knowledge with the supported/partner group. These three perspectives, since they contribute to overcoming the coloniality of knowledge and being and, with that, to designing other possible worlds (overcoming the coloniality of power), are possible, though very different, examples of ways to foster cognitive justice.

Particularly concerning decolonial technical design and technology, cognitive justice unfolds in at least two main directions: (1) a practice and construction that demand the development of a new episteme either in a top-down way or through a dialog of knowledge with the supported/partner group, being shaped or transformed as a result of that and (2) a practice and construction that cannot be accessed through pure philosophical knowledge and reflection, or, stated differently, that demands other knowledge (or disciplines) in order to be adequately grasped philosophically. Let us see each point in some more detail.

(1) Decolonial technical design and technology need to establish a dialog of knowledge due to at least four different ignorance domains that go unnoticed in the mainstream (or colonial) design and technology. First, as shown in the previous section ("Ontology"), engineering and technical design in general are a lot like art. In this regard, there is a set of elements, which encompasses part of Vincenti's design instrumentalities' contents, that are to a certain extent arbitrary and whose pluralization can allow for the conception/construction of things hitherto unachievable. A well-conducted and broad dialog of knowledge can allow for such a pluralization (Cruz, 2021).

As said earlier, the art of engineering makes evident the impossibility of technical design's total rationalization or scientification. That is something that, even being acknowledged by some/many, seems to remain a very powerful ideal or search 
(Wendt, 2018; Franssen et al., 2018). ${ }^{12}$ According to Young (2018), such impossibility has to do with three main characteristics of any engineering (or technical) design: (a) the reality that a design has to deal with is too complex to be adequately or entirely theorized, involving questions concerning the territory where the solution is to be built, its particular geographic, environmental, cultural, and political-economic situation, as well as ordinary considerations concerning functionalities and requisites; (b) designing is not only about solving clearly defined problems (to which rationalization and algorithmization can be implemented through methods such as optimization and axiomatic design) but also creatively formulating these problems throughout the design process (which is a compelling argument against reducing design to problem-solving); and (c) every new design is, to a non-neglectable extent, different from the previous ones a designer (or design team) has developed-different clients, demands, tolerances to risk, and uncertainty; different situations, political-economic conditions, territorial circumstances; etc.

Today, the design of a system often develops from a puzzle of incomplete requirements that keep changing, with design and implementation co-existing. This uncertainty is found in the growing 'wicked problems' (Rittel \& Webber, 1973) of our time, in which the interdependence between technology and social and organisational factors requires design strategies where formulation and solution develop in parallel, feeding each other, and where emergence needs to be intelligently accounted for. This means that the most prominent role of engineering today is not to solve problems but to clarify and formulate them in contexts that require holistic visions, social awareness and projective thinking. Science is essential to enable engineers to work on the parts but it is their overarching design approaches that let them see the whole. (Figueiredo, 2014, p. 28)

This, which Figueiredo calls "overarching design approaches," refers not only to engineering but also to architecture, design, and other technical disciplines. They rely on judgments of many types (like those present in the realm of the art of engineering (Cruz, 2021)) based, in Young's terms, on intuition. Intuition is "a capacity typically described as an ability to recognize appropriate solutions, relevant factors or respond to contextual features of an engineering [or technical design] task" (Young, 2018, p. 62), which, like well-known tacit knowledge, "is commonly understood to resist codification, for example, and is therefore considered to be acquired exclusively through practice and experience rather than formal education" (Young, 2018, p. 62). To train a designer on these judgmental skills, it is a cultivation of their "receptivity to relevant features of a particular environment" (Young, 2018, p. 64) that is required, not furnishing them with propositional or "algorithmic" knowledge or information known in advance.

Young does not develop his ideas any further, leaving unanswered-and not even posed-an important question: why different designers (or technical design teams) frequently develop different solutions to the same design problem (like when some

12 Cf. Footnote 10. 
company or government invites whoever be interested to propose solutions for a particular challenge)? This seems to be related to at least two different sets of elements: the structured procedures, imagery lexicon, and esthetic values deployed and the place or lenses from which the design problem is analyzed. The first set refers to the already presented art of engineering. Pluralizing them can enlarge what is designable. A possible way of achieving pluralization is through a broad dialog of knowledge in decolonial designs.

The place or lenses from which a design problem is analyzed refers to something that Simondon identifies as a necessary condition for an invention to happen, but that seems to apply to general technical design too. It has to do with a tension the inventor [or designer] experiences between what is already technically possible [or present] and what is still not but manifests itself as desirable [or required] to be (Simondon, 2008, 139-44). This tension is rooted in at least three different, but interdependent, grounds: the physical and sociotechnical environment (into which the designed solution must be incorporated); the inventor's (or designer's) technical knowledge; and the inventor's (or designer's) broader culture (which can make some problems and solutions urgent, relevant, or unseeable) (Cruz, 2021).

As argued elsewhere (Cruz, 2021), inventors or designers equipped with different knowledge or culture or present at different sociotechnical and physical environments are likely to see different possible or desired solutions to one same problem and even to identify different problems (or urgencies/necessities) worth solving. That is the second ignorance domain that bottom-up decolonial approaches to design can only overcome through an honest and broad dialog of knowledge with the supported/partner group. As said before, for such a dialog to be accomplished, care must be observed. A point worth highlighting here is that, as in the case of pluralizing the contents of Vincenti's design instrumentalities, the dialog of knowledge proposed does not entails or shapes a decolonial technical design that is more restricted, in its possible achievements, than the mainstream colonial (or modern Western) one. On the contrary, this decolonial technical design is a broader, enlarged-and, why not, improved-version of the mainstream one.

The third ignorance domain refers to another type of acknowledging the possessed knowledge's limitations. Concerning the Western technical-scientific knowledge, it is evident, for instance, with unanticipated side-effects of a technical solution that are frequently first noticed by those non-specialists that deal more directly with, or bare more heavily the effects of, that technology (Beck, 1992; Markowitz \& Rosner, 2002). That also happens when traditional or popular knowledge produces effects hitherto non-explainable by the available technical-scientific knowledge (Eglash, 2019, p. 241-244; Smith et al., 2017, p. 65-66). In all these cases, a dialog of knowledge allows technical-scientific knowledge to be enlarged either by understanding or explaining something unknown before or by studying the reality in a more contextualized or ecosystemic way and according to general guiding values other than control increasing and profit maximization (Lacey, 2014).

The fourth ignorance domain to be confronted by decolonial technical designs is already present in modern design's complex nature, as seen by Young (2018) and Figueiredo (2014). The misconception to be overcome here is, as mentioned before, identifying technical design with problem-solving, not being aware of the problems' 
(socio, political, and economic) nature, the multiple possible forms of addressing them, and the necessary socio-political efficient causes for some of these possibilities (the decolonial or liberating ones) to be conceivable and implementable (Keshavarz, 2020).

Those who want to address issues related to migrants and refugees need to develop a better understanding of the politics of the current border regime that produces and regulates refugees, asylum seekers, and undocumented migrants worldwide. It further demands that instead of using their epistemic skill of "problem-solving," designers should align with the politics of justice demanded by refugees and rethink their practice in solidarity with such politics. (Keshavarz, 2020, p. 20-1)

Only when the design problems are seen in their wider (socio, political, and economic) form can the technical design practice, regulating technical codes, and supporting knowledge and values be criticized, changed, or enlarged. ${ }^{13}$ All this presupposes solidarity with the supported/partner group and knowing their reality, needs, values, etc. In other words, this new approach to design, its new/enlarged regulating codes, and supporting knowledge and values can only arise from a committed (or solidarity) dialog in general and a broad dialog of knowledge, in particular, with the group.

Concerning the epistemic challenges posed by the top-down approaches to the decolonization of technical design and technology, they refer to enlarging and changing knowledge and ways of knowing that constitute the old episteme, as well as producing new ones. Mohamed et al. (2020) identify three main views or pathways that have been followed by the decolonial critique to the social sciences, in its effort, it could be argued, for the construction of an episteme compatible and supportive to this decolonial world that is sought. It is possible that decolonizing technology and technical design from a top-down approach might follow, or can benefit from following, these three strategies.

A decentring view of decolonisation seeks to reject an imitation of the West in all aspects of life, calling for the assertion of unique identities and a re-centring of knowledge on approaches that restore global histories and problems and solutions (Mohamed et al., 2020, p. 664).

An additive-inclusive view continues to use existing knowledge, but in ways that recognises explicitly the value of new and alternative approaches, and that supports environments in which new ways of creating knowledge can genuinely flourish. This view is invoked by works that criticise universalism in thinking, and instead advocate for localisation and pluriversalism (Mohamed et al., 2020, p. 664).

\footnotetext{
13 Feenberg provides interesting historical examples of how technical codes were forced to change due to social demands. See, for instance, the case of Minitel (1995, p. 144-166; 2017, chap. 4), boilers (2010, p. 18-21), and drug development (1995, p. 100-105; Collins \& Pinch, 1998, chap. 7).
} 
An engagement view calls directly for more critical views of science. This view calls on us to examine scientific practice from the margins, to place the needs of marginalised populations at the centre of the design and research process, and to ask where knowledge comes from-who is included and left out, in whose interest is science applied, who is silenced and what unacknowledged assumptions might be at play (Mohamed et al., 2020, p. 664).

The points to be epistemically addressed emerge from the ontological changes produced by the philosophical decolonial critique. These changes identify (i) (new) dimensions of reality to be given (more) careful attention-and to be known better-and previously over-considered dimensions to be less considered or, maybe, entirely ignored and (ii) new ideals or desirable sociotechnical orders or cosmologies: how to know it better? How to sociotechnically/cosmotechnically serve, support, or emulate it better?

As made explicit by the engagement strategy just presented, the construction of this new, decolonial episteme from a top-down approach might be helped (or ultimately rendered possible) by the bottom-up dialog of knowledge. Through such an exchange, bottom-up approaches can be made complementary to top-down ones. That, conjugated to the already mentioned potential benefits of top-down approaches to bottom-up ones (through enlarging/decolonizing the designers' imaginary), proves these approaches' potential complementarity and their possibly beneficial mutual relationship. As a result, both theoretical reflection and technical design practice can become more robust, coherent, and efficient regarding their shared ideal of overcoming the coloniality of power, knowledge, and being, replacing it with the pluriversal construction of "a world in which many worlds would coexist" (and of these worlds' supporting sociotechnical imaginaries).

(2) Finally, let us briefly analyze the claim for the incapacity of philosophy to grasp decolonial technology and technical design without some help of, for instance, the social sciences, even in the top-down approaches. One very weak corroboration of that can be drawn from Hui's and Ansari's referred works that rely heavily on anthropology and, notably, the ontological turn theories. A more robust support for this thesis, though, has to consider the colonization of Western philosophy, which is made a central pillar for the colonial episteme, unwittingly essentializing contingent aspects of technology and design, being incapable of acknowledging other dimensions or possibilities for them. All the arguments presented in this and the previous section testify, in a way or another and to a certain extent at least, to this.

That philosophy can benefit a lot from a dialog with the social sciences is something that, in the realm of philosophy of technology, is known and practiced since at least the so-called empirical turn (Franssen et al., 2016). Given that the central objects of the PT's reflection-technology and technical design-are complex empirical ones whose inevitably relational and situated nature do not allow for their complete scientification, how could PT access or know them but with the help of social sciences accounts? To make it clear, the point here is not that PT is incapable (or unwilling) of reflecting on technology and technical design when these two phenomena are taken in the broader, decolonial perspective proposed in this paper. However, since these decolonial accounts presuppose acknowledging non-universality or, 
which means the same, cherishing and supporting pluriversality, how could these plural (possible) worlds (and supporting sociotechnical orders and imaginaries) be accessed by philosophers but with the help of the social sciences? It is important to highlight that, in the decolonial theory, such pluriverse is not to be imagined by philosophers and handed to designers and the people. Philosophers do not have any privileged access to whatever worldview or values a group should choose to follow or keep. Further, there is no self-evident or objective hierarchy among such possible worlds. What philosophers can legitimately do is acknowledging (not inventing or creating!) all such irreducible diversity and trying to incorporate it into their account of technology and technical design, allowing, with that, for us to grasp better and ever more critically what technical development(s) is(are) and can be.

\subsection{Politics}

This last section focuses on some of the political aspects of the decolonial critique, enlargement, or change to PT and the conception of technology and technical design made evident or defendable by the bottom-up and top-down approaches presented. This analysis will be developed in two different directions, first analyzing technology and the design practice and then PT. In both cases, as suggested by one of this article's anonymous reviewers, Chantal Mouffe's agonistic political theory can be helpful.

According to Mouffe (2013), there is an ontologic interdict to any sort of political "consensus without exclusion" (p. 8), namely the condition of creating a "they" in order for us to construct a "we," a collective identity, which is the basis for the passions that are the driving forces in the political field (p. 17-18). In other words, any identity can only arise accompanied by the creation (or acknowledgment) of a group of people who are irreconcilably distinct from ourselves (p. 15-16). Hence, the order a group might want to advance politically will inevitably conflict with that which some other group stands for. Any prevailing order will thus always be contingent, the result of a particular hegemony, that is, a particular arrangement of power that prevailed over other articulations (and supporting identities).

[...] to acknowledge [such] radical negativity implies recognizing not only that the people is multiple, but that it is also divided. Such a division cannot be overcome; it can only be institutionalized in different ways, some more egalitarian than others. According to this approach, radical politics consists in a diversity of moves in a multiplicity of institutional terrains, so as to construct a different hegemony. It is a 'war of position' whose objective is not the creation of a society beyond hegemony, but a process of radicalizing democracy - the construction of more democratic, more egalitarian institutions. (Mouffes, 2013, p. 9)

Although consensus is unachievable (for it would require a universal identity), the different identities and worlds they support can deal with one another in an agonistic, instead of antagonistic, way. In the first case, the opponents are seen as adversaries to be defeated in a (political) game whose rules are agreed upon by all sides. 
Plus, some fundamental rights (e.g., equity, dignity, liberty) are guaranteed, even though their meaning will always be a matter of interpretation and dispute by each side. All that offers necessary conditions for difference not to decay into violence, with all parties playing according to the rules to advance their power situation and become (or remain) hegemonic (Mouffes, 2013, p. 18-19).

In the antagonistic situation, the groups see their opponents as enemies to be destroyed. There is no possibility of non-hegemonic groups playing the game of institutional politics. Further, some fundamental rights are not guaranteed, making violence a seductive way for the silenced to fight for their voices, identities, and hegemonies. That is why agonism must always be preferred (Mouffes, 2013, p. 18-19, 98).

In an agonistic politics [...] the antagonistic dimension is always present, since what is at stake is the struggle between opposing hegemonic projects which can never be reconciled rationally, one of them needing to be defeated. It is a real confrontation, but one that is played out under conditions regulated by a set of democratic procedures accepted by the adversaries. [...] The prime task of democratic politics is not to eliminate passions or to relegate them to the private sphere in order to establish a rational consensus in the public sphere. Rather, it is to 'sublimate' those passions by mobilizing them towards democratic designs, by creating collective forms of identification around democratic objectives. (Mouffe, 2013, p. 19)

If consensus is not possible, being agonism the best option, it is not only that a universal and harmonious sociotechnical or cosmotechnical order is unachievable, the very maintenance of the agonistic agora and its supporting rules requires contenders strong enough not to allow the hegemony in place to undermine its opponents' political legitimacy, potential, and means. Decolonial technical designs like the four types presented earlier work in these two complementary realms-sociotechnical/cosmotechnical pluriverse and counter-hegemonic political power-both sociotechnically/cosmotechnically emulating the worlds (or identities, that is, worldviews, values, and ideals) non-hegemonic groups might legitimately demand (in agonistic terms) and politically empowering them.

Technical developments can be agonistic in at least one other way. That happens when the political dispute (and supporting identity diversity) is present inside the development that is sought, something that frequently not occurs in the discussed decolonial designs, which work with smaller and more cohesive groups and whose approach intentionally aims to strengthen the group's identity. Popa et al. (2020) analyze this type of "inside agonism" in the discussions concerning responsible research initiatives where multiple sociotechnical alternatives are faced or brought/ supported by different stakeholders, like in the ongoing discussions concerning the so-called hydrogen economy. Their agonistic approach can be defined this way:

In the context of responsible innovation, the agonistic approach will seek to multiply and foster social practices of conflict, practices where multiple values and value interpretations can compete. The backdrop and organizing principle of such practices is not a 'neutral' ideal of rationality or a shared goal, 
but rather the ethico-political bonds of citizenship. The innovation community must thus be organized not as a universitas - an association of people with an established (universal or common) goal and values that select those who seek membership_but as a societas — an association without an established ideal or a shared goal but with a minimal agreement on practices of civility and competition and a common understanding that these rules are but a temporary modus vivendi (Popa et al., 2020, p. 7).

"Inside agonism" seems applicable with two distinct and perhaps complementary intentions (or in two different ways). The first one is actively provoking all the stakeholders involved to acknowledge not only possible values and value interpretations but also sociotechnical solutions that can embody them. It thus also works as a way of not sticking so fast to one particular solution, which could allow for the conception of a solution that can accommodate, to a certain extent at least, some of the non-hegemonic actors' values too (taking advantage of this technology's potential plasticity that Feenberg (2010, p. 73-76), drawing on some of Simondon's ideas, calls concretization). The second possible intention (or way of use) of "inside agonism" is to support non-hegemonic actors in this agonistic technological agora in order for them to be better equipped to play with the hegemonic stakeholders and guarantee some fundamental conditions for the former to sociotechnically subsist, if only marginally.

There are cases where "outside" and "inside" technical agonisms are, or seem to be, conjugated. Popular engineering has been trying that since it arose. Internally, strengthening the group and advancing alongside them the local sociotechnical order they may want. Externally, fighting with them in the broader agonistic sociotechnical agora, they belong to for technical regulations or specific policies that can ensure the existence of such alternative order alongside the hegemonic one (Fraga et al., 2020). That is the case, for instance, of cooperatives of waste pickers in the Brazilian city of Belo Horizonte whose internal work and arrangement were (and keep being) improved and the external conditions for their existence are assured for now. As for the external conditions, the cooperatives, with the support of popular engineers, succeeded in convincing state legislators to interdict the incineration of recyclable trash and the municipality to contract/pay the cooperatives for collecting such material. All that particular arrangement was built in the wake of the local implementation of the country's National Solid Waste Policy (Varella et al., 2020).

Analyzed according to the concept of sociotechnical imaginaries, it can be said that such an intervention clearly helps other possible sociotechnical imaginaries to be conceived/built and thrive/advance, following the four steps identified by Jasanoff (2051b): origin stories, material or institutional embeddings, resistance, and extension.

In sum, decolonial designs testify to the intrinsically political character of technical development for nurturing identities and sociotechnical imaginaries, trying sociotechnical ways of emulating them, and fighting for these ways' existence in the broad and agonistic agora of society's everyday life. Denying such a trait can only benefit the ruling hegemony and reinforce the episteme and identity that this arrangement of power shapes and by which it is shaped. 
At any rate, what both decoloniality and agonism stand for is not the imposition of a new universal but the construction of "a world in which many worlds would coexist." PT can have at least two different roles in the construction of this pluriversal or radically more egalitarian order: developing theoretical instruments for an honest and deed critique of the status quo and the multiple alternatives to it and advancing the reflections that can support diverse and legitimate alternatives for the hegemonic coloniality. Both tasks seem to need much more effort. Indeed, even though the "pro people's liberation from oppression" discourse can find a good degree of acceptance among philosophers of technology, we seem much less open to criticize many of our discipline's standards and truths.

One example of such resistance is the difficulty to acknowledge that incorporating the supported/partner group's knowledge into the produced technology and even the most technical steps of the designing practice can not only be legitimate but also liberating for technological development. Instead, when such fertilization is identified, it is commonly viewed by mainstream philosophy and technical disciplines as an ideologic corruption to be corrected, or, with luck, as a locally justified approach (say, to ensure some ethnic construction), but with little, if any, relevance to understanding and practicing technical design (and producing technology) in general.

It is not just the epistemic canons of the Western regime of truth (i.e., Western technoscience and philosophy as knowledge, ways of knowing, and institutions) that tend to be defended from any threat. Western ways of being (or identities) and (political-economic) power arrangements are frequently and a critically taken as universal or, at least, as the best possible ones. Everything else is deemed as either wrong or the precarious achievements that precarious actors with precarious training and from precarious territories could not do better.

That, which simply illustrates the degree to which PT remains colonized, results from the conjugation of multiple factors. Among them, one can find (i) PT mainly being practiced in the global North and written in English, by an elite (university teachers), with little to no interest for the empirical; (ii) PT trying to be taken as a relevant research area by academic, political, and economic actors and institutions, thus submitting itself to their standards, priorities, and evaluative criteria; and (iii) PT mainly not committing to poor, marginalized real people's fate or (sociotechnical) problems.

A way out of such colonial imprisonment of PT is pluralizing it. In Brazil, affirmative actions held by the Worker's Party's federal administrations (2003-2016) led, among other things, to the admission of poor and black young people to the country's best-evaluated universities (which turn out to majorly be public institutions). Some results of that have recently started to be felt in some engineering schools through (1) students' demands for a more socially committed engineering teaching and practice and (2) students creating collectives for performing such committed engineering, or associating to existent collectives and making them and their interventions somewhat more popular/grassroots. Perhaps, if PT likewise encourages its occupation by such unprivileged people, with their usually unseen needs, identities, experiences, and knowledges, it can open ways for navigating itself out of the colonial ivory tower it finds itself in. 
The challenge, anyway, is to overcome the illusion of a political "consensus without exclusion," acknowledging legitimate sociotechnical diverse horizons and their theoretical demands for improving their power position, with particular attention to underserved (or disempowered) groups. To a certain extent, PT needs to become more agonistic itself, getting rid of the somewhat deceiving and never achievable ideal of neutrality. A way or another, we all talk, act, and do our jobs (as professional philosophers or whatever) from a particular individual and collective, human, and ecosystemic place. As in technical design, plural values, knowledges, and perspectives can allow for a better and wider PT to emerge. However, PT does have to be willing, and be able, to bear agonistically a wider political diversity and more radical democratic disputes inside its ranks. This paper aims to be a contribution to increasing both PT's diversity and internal agonistic disputes.

\section{Closing Remarks}

As part of the colonial episteme or regime of truth produced by and supporting the colonial power arrangement articulated around neo-liberal and globalized capitalism, philosophy needs to be decolonized. That is necessary for decoloniality (of power, knowledge, being) to be possible and for the philosophical reflection to be widened and, maybe, pluralized. This article proposed a way of decolonizing philosophy of technology (PT) by enlarging its colonial matrix. However, it can be the case (in the future?) that other sorts of decolonization cannot be reconcilable with the (by then (partially) decolonized) Western PT. In this situation, conceiving, knowing, and constructing other possible worlds or this "world in which many worlds would coexist" might demand plural, distinct philosophies, not reducible to, or translatable into, one another.

The decolonizing pathway followed tried to conjugate Hui's and Ansari's topdown proposals to the decolonization of technology and technical design with some bottom-up decolonial approaches to technical design. Even though such a conjugation was tried, the article's most significant contributions are derived from the bottom-up approaches.

The PT's decolonization addressed here encompasses three different areas: ontology, epistemology, and politics. Concerning the nature of technology or technical design, it was claimed that they have a widened relational mode of existence; the design practice is partly an art; care (as labor/work, affect/affections, ethics/politics) is fundamental for a decolonial design; and the technical design is always more than (or cannot be reduced to) a problem-solving activity.

Concerning the epistemic decolonizations, it was shown that decolonial designs must draw on a (decolonial) broad dialog of knowledge between the technical team and the supported/partner groups, which potentially enlarges what is conceivable and implementable; through such a dialog, the supported/partner group can contribute with knowledge unknown by the technical team, and that also presents itself as a way for enlarging the technical-scientific knowledge, research approach, or program/ agenda; the problems to be sociotechnically solved must be known in their broader 
social, political, and economic nature; there seem to exist three complementary strategies for top-down approaches to decolonization to use when constructing new epistemes (or regimes of truth); philosophy is incapable of grasping decolonial technical design and technology, unless it also relies, for instance, on the accounts of the social sciences.

Finally, concerning politics, it was defended that decolonial designs can support non-hegemonic groups both internally (empowering them and locally designing the sociotechnical/cosmotechnical worlds they legitimately might seek) and externally (fighting for the conditions of these alternative worlds to co-existence alongside the hegemonic one); PT must grow more agonistic, embracing or encouraging a wider political diversity and more radical democratic disputes inside its ranks.

If all that seems to help decolonize PT, its decolonization is not the same as making PT decolonial, that is to say, fostering decoloniality through PT. A decolonial PT can be achieved in different ways and will only succeed as the result of the work of a collectivity, not of a few (isolated) individuals. Among these possible ways, a decolonial PT can help decolonize ourselves and our students, committing (many or some of) us to fostering PT, technology, or technical design decolonization and to the decolonial co-conception and co-construction of other possible worlds. Second, a decolonial PT can choose decoloniality (of power, knowledge, and being) as its research agenda or research topics. Third, a decolonial PT can associate itself with engineers, designers, architects, social scientists, etc., in their shared ideal of decolonizing technology and technical design. Fourth, a decolonial PT can associate itself with decolonial social movements or organized groups in their shared ideal of building decolonial possible worlds.

Decolonizing PT and making it decolonial means (or presupposes) getting closer to the empirical reality (or getting rid of the isolated ivory tower) and somehow committing to its transformation. This way, decolonial approaches to technical design can help philosophers doubly: showing some singular forms of practicing design and producing (non-conventional) technology; and offering philosophers decolonial designers' dialogic, careful, and committed posture as a possible, inspiring example of how to approach the empirical reality, see and know it also through the lenses, worldviews, and knowledge of the poor or marginalized, and associate with them in the struggle to transform the world.

Although a decolonial PT cannot save or liberate the world (from coloniality) alone, it can play a relevant role in this process, as sketched above. Hopefully, that will be the case, at least for part of our discipline and ourselves.

Funding This work was supported by the São Paulo Research Foundation (FAPESP) under Grant number 2018/20563-3.

\section{Declarations}

Conflict of Interest The author is a member of the Brazilian popular engineering network (Repos).

Open Access This article is licensed under a Creative Commons Attribution 4.0 International License, which permits use, sharing, adaptation, distribution and reproduction in any medium or format, as long as 
you give appropriate credit to the original author(s) and the source, provide a link to the Creative Commons licence, and indicate if changes were made. The images or other third party material in this article are included in the article's Creative Commons licence, unless indicated otherwise in a credit line to the material. If material is not included in the article's Creative Commons licence and your intended use is not permitted by statutory regulation or exceeds the permitted use, you will need to obtain permission directly from the copyright holder. To view a copy of this licence, visit http://creativecommons.org/licen ses/by/4.0/.

\section{References}

Ansari, A. (2018) What knowledge for a decolonial agenda in the philosophy of technology? Published in distributed. David Blamey \& Brad Haylock (Eds.). Open editions.

Ansari, A. (2019). Decolonizing design through the perspectives of cosmological others: Arguing for an ontological turn in design research and practice. XRDS, 26(2), 1-4. https://doi.org/10.1145/ 3368048

Araújo, F. and Rufino, S. (2021) Rede de Engenharia Popular Oswaldo Sevá. In: C. Alvear, C. Cruz, and J. Kleba. Engenharias e outras práticas técnicas engajada - Vol. 1: redes e movimentos. Campina Grande: EDUEPB.

Araújo, F., et al. (2019). Dialética da autogestão em empresas recuperadas por trabalhadores no Brasil. Lutas Anticapital.

Bannon, L., \& Ehn, P. (2013). Design: Design matters in participatory design. In J. Simonsen \& T. Robertson (Eds.), Routledge international handbook on participatory design (pp. 37-63). Routledge.

Barthélémy, J.-H. (2014). Simondon. Les Belles Lettres.

Beck, U. (1992). Risk society - Towards a new modernity. SAGE Publications Ltd.

Bellacasa, M. (2017). Matters of care: Speculative ethics in more than human worlds. University of Minnesota Press.

Collins, H., \& Pinch, T. (1998). The golem at large: What you should know about technology. Cambridge University Press.

Cortés-Rico, L. and Piedrahita-Solórzano, G. (2015) Participatory design in practice: The case of an embroidered technology. In 15th IFIP TC 13 international conference, eds. Abascal, J. et al. Bamberg, Germany: September 14-18.

Cruz, C. (2020) Assessing grassroots engineering applications in Brazil. Paper presented at 2020 ASEE Virtual Annual Conference Content Access, Virtual Online. https://peer.asee.org/34176

Cruz, C. (2021a). Brazilian grassroots engineering: A decolonial approach to engineering education. European Journal of Engineering Education. https://doi.org/10.1080/03043797.2021.1878346

Cruz, C. (2021b) Valores estéticos, acervos imagéticos e procedimentos estruturados: ampliando e descolonizando a reflexão filosófica sobre a tecnologia. Trans/Form/Ação, Marília, 44, 207-230. https://doi.org/10.1590/0101-3173.2021.v44dossier.11.p207

Cruz, C. (2021). Decolonial Approaches to Technical Design: Building Other Possible Worlds and Widening Philosophy of Technology. Techné: Research in Philosophy and Technology (forthcoming).

Cruz, C., \& Rufino, S. (2020). Engenharia Popular: Histórias, Práticas e Metodologias de Intervenção. Repos.

Dagnino, R., Brandão, F., and Novaes, H. (2004) Sobre o marco analítico-conceitual da tecnologia social. In: Lassance Jr. et al. (Ed.) Tecnologia social - Uma estratégia para o desenvolvimento. Rio de Janeiro: Fundação Banco do Brasil, p. 15-64.

Dussel, E. (2012). Transmodernity and interculturality: An interpretation from the perspective of philosophy of liberation. TRANSMODERNITY: Journal of Peripheral Cultural Production of the LusoHispanic World, 1(3), 28-59.

Eglash, R. Anti-Racist Tchnoscience: a generative tradition. (2019) In: R. Benjamin (Org.). Captivating technology: race, carceral technoscience, and liberatory imagination in everyday life. Durham and London: Duke University Press, p. 228-51. 
Escobar, A. (2018). Designs for the Pluriverse: Radical interdependence, autonomy, and the making of worlds. Duke University Press.

Estermann, J. (2006). Filosofía andina: Sabiduría indígena para un mundo nuevo. ISEAT.

Estermann, J. (2014). Colonialidad, descolonización e interculturalidad: Apuntes desde la Filosofía Intercultural. Polis Revista Latinoamericana, 38, 1-18.

Feenberg, A. (1995). Alternative modernity: The technical turn in philosophy and social theory. University of California Press.

Feenberg, A. (2010). Between reason and experience: Essays in technology and modernity. MIT Press.

Feenberg, A. (2017). Technosystem: The social life of reason. Harvard University Press.

Ferguson, E. (1992). Engineering and the mind's eyes. The MIT Press.

Figueiredo, A. (2014) On the historical nature of engineering practice. In: Bill Williams; José Figueiredo; James Trevelyan (Ed.). Engineering practice in a global context: Understanding the technical and the social. Leiden (Netherlands): CRC press/Balkema, p. 7-32.

Foucault, M. (1980) Power/knowledge - selected interviews \& other writings (1972-1977). Trans. Colin Gordon, Leo Marshall, John Mepham \& Kate Soper. : Pantheon Books.

Foucault, M. (2000). Power. New Press.

Fraga, L., Alvear, C., \& Cruz, C. (2020). Na trilha da contra-hegemonia da engenharia no Brasil: da Engenharia e Desenvolvimento Social à Engenharia Popular. Revista Iberoamericana de Ciencia, Tecnología y Sociedad, 43(15), 209-232.

Franssen, M., Vermaas, P., Kroes, P., \& Meijers, A. (Eds.). (2016). Philosophy of technology after the empirical turn. Dordrecht: Springer. https://doi.org/10.1007/978-3-319-33717-3

Franssen, M., Lokhorst, G., and van de Poel, I. (2018) "Philosophy of technology." The Stanford Encyclopedia of Philosophy (Fall 2018 Edition), Edward N. Zalta (ed.), https://plato.stanford.edu/archives/ fall2018/entries/technology/.

Freire, P. (2005a). Pedagogy of the oppressed. Continuum.

Freire, P. (2005b). Extension or communication? In: Freire, P. Education for Critical Consciousness. London: Continuum, p. 86-146.

Freire, P., \& Shor, I. (1987). A pedagogy for liberation: Dialogues on transforming education. MACMILLAN EDUCATION LTD..

Guizzo, I. (2019). Reativar territórios: o corpo e o afeto na questão do projeto participativo. Quintal Edições.

Guizzo, I. (2021) Um Planeta Danificado e Uma Terceira Margem do (Re)Construir. In: C. Alvear, C. Cruz, and J. Kleba. Engenharias e outras práticas técnicas engajadas - Vol. 1: redes e movimentos. Campina Grande: EDUEPB..

Hui, Y. (2016) The question concerning Technology in China: An essay in Cosmotechnics. UK: Urbanomic Media Ltd.

Hui, Y. (2017). On cosmotechnics: For a renewed relation between technology and nature in the anthropocene. Techné: Research in Philosophy and Technology, 21(2-3), 319-341. https://doi.org/10. 5840/techne201711876

Jasanoff, S. (2015a). Future imperfect: Science, technology, and the imaginations of modernity. In S. Jasanoff \& S.-H. Kim (Eds.), Dreamscapes of modernity: Sociotechnical imaginaries and the fabrication of power (pp. 1-33). The University of Chicago Press.

Jasanoff, S. (2015b). Imagined and invented worlds. In S. Jasanoff \& S.-H. Kim (Eds.), Dreamscapes of modernity: Sociotechnical imaginaries and the fabrication of power (pp. 321-342). The University of Chicago Press.

Jimenez, A., \& Roberts, T. (2019). Decolonising neo-liberal innovation: Using the Andean philosophy of 'Buen Vivir' to reimagine innovation hubs. P. Nielsen and H. C. Kimaro (Eds.): ICT4D 2019. IFIP AICT, 552, 180-191.

Keshavarz, M. (2020). Violent compassions: Humanitarian design and the politics of borders. Design Issues, 36(4), 20-32.

Kleba, J. B., \& Cruz, C. (2021). Empowerment, Emancipation and Engaged Engineering. International Journal of Engineering, Social Justice, and Peace, 8(2), 28-49. https://doi.org/10.24908/ijesjp.v8i2. 14380

Lacey, H. (2014). Scientific research, technological innovation and the agenda of social justice, democratic participation and sustainability. Scientiae Studia. São Paulo, 12(special issue), 37-55. 
Maldonado-Torres, N. (2008). La descolonización y el giro des-colonial. Tabula Rasa, 9, 61-72.

Maldonado-Torres, N. (2009) El pensamiento filosófico del "giro descolonizador". In: Dussel, H., Mendieta, E., and Bhohórquez, C. (Ed.) El pensamiento filosófico latinoamericano, de Caribe y "latino" (1300-2000): historia, corrientes, temas y filósofos. México: Siglo XXI: Centro de Cooperación Regional para la Educación de Adultos en América Latina y el Caribe, p. 682-97.

Markowitz, G., \& Rosner, D. (2002). Deceit and denial: The deadly politics of industrial pollution. University of California Press.

Mignolo, W. (2007) El pensamiento decolonial: desprendimiento y apertura: Un manifiesto. In S. CastroGómez and R. Grosfoguel (Eds.). El giro decolonial: Reflexiones para una diversidad epistémica más allá del capitalismo global. Bogotá: Siglo del Hombre Editores; Universidad Central, Instituto de Estudios Sociales Contemporáneos y Pontificia Universidad Javeriana, Instituto Pensar, p. 25-46.

Mignolo, W. (2011a). Epistemic disobedience and the decolonial option: A manifesto. Transmodernity: Journal of Peripheral Cultural Production of the Luso-Hispanic World, 1(2), 44-66.

Mignolo, W. (2011b). The darker side of Western modernity: Global futures, Decolonial options. Duke University Press.

Mignolo, W. (2012) The darker side of Western modernity: Global futures, Decolonial options. Duke University press, 2012.

Mohamed, S., Png, M., \& Isaac, W. (2020). Decolonial AI: Decolonial theory as sociotechnical foresight in artificial intelligence. Philosophy \& Technology, 33, 659-684.

Mouffe, C. (2013). Agonistics: Thinking the world politically. Verso.

Nhemachena, A. and Matowaniyka, J. (2020) Centuries-old colonial/Imperial denialism of African originality: An introduction to Decolonising STEM in Africa. A. Nhemachena, N. Hlabangane, and J. Matowaniyka (Org.). Decolonising science, technology, engineering and mathematics (STEM) in an age of Technocolonialism: Recentring African indigenous knowledge and belief systems. Bamenda (Cameroon): Langaa Research \& Publishing CIG, p. 1-62.

Pérez-Bustos, T. (2017) Thinking with care. Unraveling and mending in an ethnography of craft embroidery and technology. Revue d'anthropologie des connaissances, 11, 1, p. a-u.

Pérez-Bustos, T., \& Márquez, S. (2016). Destejiendo puntos de vista feministas: reflexiones metodológicas desde la etnografía del diseño de una tecnología. Revista Iberoamericana CTS, 31(11), 147-169.

Popa, E., Blok, V., \& Wesselink, R. (2020). An agonistic approach to technological conflict. Philosophy \& Technology. https://doi.org/10.1007/s13347-020-00430-7

Quijano, A. (1992). Colonialidad y modernidad/racionalidad. Perú Indígena, 13(29), 11-20.

Quijano, A. (1999). Colonialidad del Poder, Cultura y Conocimiento en América Latina. Dispositio, 24(51), 137-148.

Rivera, R., Cortés-Rico, L., Pérez-Bustos, T., \& Franco-Avellaneda, M. (2016). Embroidering engineering: A case of embodied learning and design of a tangible user interface. Engineering Studies, 8(1), 48-65.

Robertson, T. and Simonsen, J. (2013) Participatory design - an introduction. In: J. Simonsen and Robertson, T. (Eds.) Routledge international handbook on participatory design. London \& new York: Routledge, p. 1-17.

Santos, B. (2016). Epistemologies of the south: Justice against epistemicide. Routledge.

Schultz, T., Abdulla, D., Ansari, A., Canli, E., Keshavarz, M., Kiem, M., Martins, L., \& Oliveira, P. (2018). What is at stake with decolonizing design? A roundtable. Design and Culture, 10(1), $81-101$.

Simondon, G. (1989 [1958]) Du mode d'existence des objets techinques. Paris: Aubier, 1989 [1958].

Simondon, G. (2008 [1965-6]) Imagination et Invention. Chatou: Les Éditions de La Transparence, 2008 [1965-6].

Simondon, G. (2009 [1968]) Entretien sur la mécanologie. Revue de synthèse: tomo 130, $6^{\mathrm{a}}$ série, $\mathrm{n}^{\mathrm{o}} 1, \mathrm{p}$. 103-132.

Smith, A., Fressoli, M., Abrol, D., Arond, E., \& Ely, A. (2017). Grassroots innovation movements. Routledge.

Sutz, J. (2021) Thinking otherwise: The ambiguous role of technological imaginaries in development processes. $22^{\text {nd }}$ biennial conference of the Society for Philosophy and Technology, Lille, June $28^{\text {th }}-$ $30^{\text {th }}$ 2021. https://www.youtube.com/watch?v=BaH4OCKQgGo 
Trevelyan, J. (2014). Towards a theoretical framework for engineering practice. In B. Williams, J. Figueiredo, \& J. Trevelyan (Eds.), Engineering practice in a global context: Understanding the technical and the social (pp. 33-59). CRC Press/Balkema.

Van de Poel, I. (2009). Values in Engineering Design. In A. Meijers (Ed.), Philosophy of technology and engineering science (pp. 973-1006). Elsevier B. V.

Van der Velden, M., \& Mörtberg, C. (2015). Participatory design and design for values. In J. Van den Hoven, P. Vermaas, \& I. Van de Poel (Eds.), Handbook of ethics, values, and technological design (pp. 41-66). Springer.

Varella, C., Campos, L., Lima, F., Souza, M., Manzanares, R.; Tofanelli, V., and Valle, W. (2020) Alternativas de produção e economias alternativas. In: Cruz, C.; Rufino, S. (Org.). Engenharia popular: histórias, práticas e metodologias de intervenção. Natal (RN): Repos, p. 81-106. https://repos.milha ral.org/files/2020/10/Livro-REPOS-volume-1-eBook-completo-1.pdf.

Vincenti, W. (1990). What engineers know and how they know it. London: The John Hopkins University Press.

Young, M. (2018) Intuition and ineffability: Tacit knowledge and engineering design. In: Albrecht Fritzsche and Sascha Julian oks (Ed.). The future of engineering: Philosophical foundations, ethical problems and application cases. Springer, p. 53-68.

Wendt, T. (2018) Arational design. In: Pieter E. Vermaas and Stéphane vial (Org.). Advancements in the philosophy of design. Switzerland: Springer international publishing AG, p. 101-120.

Winner, L. (1986) Do artifacts have politics? In: L. Winner (Org.) The whale and the reactor: A search for limits in an age of high technology. Chicago: University of Chicago Press, p. 19-39.

Publisher's Note Springer Nature remains neutral with regard to jurisdictional claims in published maps and institutional affiliations.

\section{Authors and Affiliations}

\section{Cristiano Codeiro Cruz ${ }^{1}$}

1 Instituto Tecnológico de Aeronáutica (ITA), São José dos Campos, Brazil 